\title{
LINGKUNGAN HIDUP SEBAGAI SUBJEK HUKUM: REDEFINISI RELASI HAK ASASI MANUSIA DAN HAK ASASI LINGKUNGAN HIDUP DALAM PERSPEKTIF NEGARA HUKUM
}

\author{
Abdurrahman Supardi Usman \\ Biro Hukum Kementerian Pertanian RI \\ Jl. R. M. Harsono, No. 3 Jakarta Selatan \\ abdurrahmansupardiusman@gmail.com
}

\begin{abstract}
Inspired by "Should Trees Have Standing? Toward Legal Rights for Natural Objects" (Christopher D. Stone, 1974) that popularized the doctrin: "environment as a legal subject". This thesis was directly elaborating the relation between the constitutional aspect of the "state of law" and its admission of environmental rights, not just about the dimention of the philosophy of law but beyond of it: this thesis was discuss about the theoretical dimention of law and its relevance in Indonesia. At least there are two monumental cases in the world which were become the landmark case of environmental disputes resolution based of by the doctrin of ecocracy. In the dissenting opinion of the judge William O. Douglas in Sierra Club vs Morton's case, United Stated of America (1972) and in the appeal decision of the Wheeler vs the Government of the provincial of Roja's case, Ecuador (2011). Those cases had opened a new perspective in the legal proceeding that the environment had be approved as a legal person. In other words, the environment had recognized as a legal subject. Then, by using the conseptual approach and comparative of law approach, this thesis had elaborated the relevance of this doctrin: "The Environment as a Legal Subject" in Indonesian context then verified it with the related legal theories. Besides it all, in this thesis also discuss the relation between of the environmental legal protection and the state of law concept in the ecocracy and constitualism perspective framework. Hopefully this thesis would be the steping stone to realize the constitutionalisation the environment rights and to realize the legal standing innovation in the environmental disputes resolution.
\end{abstract}

Keywords: Environmental Law, Constitution, Ethics, Legal Standing

\begin{abstract}
Abstrak
Terinspirasi oleh Should Trees Have Standing? Toward Legal Rights for Natural Objects (Christopher D. Stone, 1974) yang memopulerkan doktrin "lingkungan hidup sebagai subjek hukum" melalui bahasannya yang merombak pemikiran filsafat hukum. Tulisan ini mengelaborasi secara langsung relasi antara aspek konstitusional dari sebuah negara hukum (yang berorientasi pada Hak Asasi Manusia) dengan pengakuan hak asasi lingkungan hidup yang bukan hanya pada tataran filsafat, lebih jauh pada dimensi teoritis dan relevansinya di Indonesia. Secara global setidaknya terdapat dua kasus monumental yang menandai hadirnya pengaruh doktrin ekokrasi dalam memandang permasalahan hukum lingkungan. Dilacak dalam dissenting opinion hakim William O. Douglas atas kasus Sierra Club vs Morton,
\end{abstract}


Amerika Serikat (1972) dan dalam putusan tingkat banding atas kasus Wheeler vs pemerintah Provinsi Roja, Ekuador (2011). Kedua kasus tersebut membuka perspektif baru dalam praktek hukum bahwa alam dipandang sebagai penyandang hak-hak hukum. Dengan kata lain lingkungan hidup sebagai subjek hukum. Selanjutnya dengan pendekatan konseptual dan perbandingan hukum, tulisan ini mengelaborasi relevansi doktrin: "lingkungan hidup adalah subjek hukum" dalam konteks etika lingkungan dan konstirusionalisme ekokrasi. Diharapkan dapat bermuara pada konstitusionalisasi hak lingkungan hidup dan pembaharuan legal standing dalam sengketa lingkungan demi terwujudnya kemaslahatan bagi seluruh alam.

\section{Kata Kunci: Hukum Lingkungan, Konstitusi, Etika, Legal Standing.}

\section{A. Pendahuluan}

Membicarakan hak asasi manusia dan relasinya dengan lingkungan hidup tentunya akan bermuara pada perbincangan mengenai Hak atas lingkungan hidup (the right to environment) dan hak atas pembangunan (the right to development). The right to environment dan the right to development menjadi populer untuk dibicarakan berdampingan sejak diselenggarakannya Konferensi Lingkungan Hidup Manusia oleh PBB pada tahun 1972 di Stockholm Swedia (dikenal populer sebagai konferensi Stockholm 1972). Pada 16 Juni 1972 di akhir sidang konferensi tersebut, disahkan hasil-hasil berupa: Stocholm Declaration, Rencana Aksi dan rekomendasi tentang pelembagaan dan keuangan aksi tersebut. Turut pula disepakati pada konferensi ini (dalam suatu resolusi khusus) bahwa tanggal 5 Juni disepakati sebagai hari lingkungan hidup sedunia (World Environment Day). ${ }^{1}$ Dalam Konferensi Stockholm 1972 ini pembangunan berwawasan lingkungan pertama kali disepakati secara global. Secara tegas disebutkan dalam principle 13 Declaration of the United Nations Conference on the Human Environment ini, bahwa:

In order to achieve a more rational management of resources and thus to improve the environment, States should adopt an integrated and co-ordinated approach to their development planning so as to ensure that development is compatible with the need to protect and improve environment for the benefit of their population. ${ }^{2}$

Konsep pembangunan berkelanjutan kemudian dikaji lebih lanjut dalam Konferensi Tingkat Tinggi di Rio de Jeneiro, Brazil pada tanggal 3 sampai 14 Juni 1992. Salah satu hasil dari KTT ini adalah adanya kesepakatan atas 3 (tiga) pilar utama yang mendukung pembangunan berkelanjutan, yakni pembangunan ekonomi, pembangunan sosial, dan perlindungan lingkungan hidup. ${ }^{3}$ KTT ini juga diantaranya menghasilkan Deklarasi Rio dan Agenda 21. Secara garis besar Agenda 21 menggambarkan kerangka kerja dari suatu rencana

\footnotetext{
${ }^{1}$ Munadjat Danusaputra, Hukum Lingkungan, Buku I, Binacipta, 1985, h. 213-214.

${ }^{2}$ Ibid, h. 219.

${ }^{3}$ Mukhlish dan Mustafa Lutfi, Hukum Administrasi Lingkungan Kontemporer, Cetakan Pertama, Malang: Setara Press, 2010, h.35.
} 
kerja yang disepakati oleh masyarakat internasional, yang bertujuan untuk mencapai pembangunan berkelanjutan pada abad ke-21 tersebut. ${ }^{4}$

Merupakan sebuah keniscayaan bahwa perlindungan dan pengelolaan lingkungan hidup sebagai aspek fundamental atas keberlangsungan dan terjaminnya berbagai jenis hak asasi manusia seperti hak untuk hidup, hak atas hidup yang layak, dan hak atas kesehatan dan lingkungan yang bersih. Oleh karena itu lingkungan hidup dipandang sebagai varian instrumental dari konsepsi umum hak asasi manusia, yaitu manusia atau warga negara berhak atas lingkungan yang sehat dan terjaga kebersihannya. Perlindungan hukum terhadap lingkungan hidup (khususnya di Indonesia) masih didasarkan pada kepentingan manusia yang diakui haknya atas lingkungan hidup yang layak. Perusakan atau pencemaran lingkungan dipandang sebagai sesuatu yang salah secara hukum oleh karena dampaknya yang melanggar hak manusia bukan karena melanggar hak dari alam (lingkungan hidup itu sendiri). Nilai-nilai hak asasi manusia yang bersifat universum tersebut selanjutnya ditransformasikan ke dalam produk-produk hukum nasional di berbagai negara untuk melindungi kepentingan kemanusian warga negara tersebut.

Kasus Sierra Club v. Morton (1972) menjadi salah satu kasus landmark dalam wajah baru perlindungan hukum lingkungan hidup. Kasus tersebut merupakan gugatan yang mendalilkan hak gugat lingkungan hidup yang pertama, yaitu Sierra Club menggugat US Forest Service atas kerugian lingkungan hidup yang disebabkan pembangunan Mineral King di dekat Sequoia National Park, Amerika Serikat. ${ }^{5}$ William O. Douglas salah satu hakimnya, mengajukan dissenting opinion $^{6}$ yang sangat monumental. Dissenting opinion tersebut kemudian memicu diskursus secara meluas di berbagai negara dalam hal penegasan hak bagi lingkungan hidup dan/atau sumber daya alam untuk memiliki kedudukan hukum dalam mempertahankan perlindungan dirinya sendiri.

Pada Konteks Indonesia, Lingkungan hidup yang baik dan sehat merupakan hak asasi setiap warga negara Indonesia sebagaimana diamanatkan dalam Pasal $28 \mathrm{H}$ ayat (1) UndangUndang Dasar Negara Republik Indonesia Tahun 1945. Sejalan dengan itu pada Pasal 28I (4) dan (5) Undang-Undang Dasar Negara Republik Indonesia Tahun 1945 ditegaskan bahwa perlindungan, pemajuan, penegakan, dan pemenuhan hak asasi manusia adalah tanggung jawab negara, terutama pemerintah.

Pemenuhan dan penjaminan hak asasi atas lingkungan hidup yang baik dan sehat, sebagaimana dijamin dalam konstitusi, memerlukan instrumen-instrumen hukum yang berorientasi pada pemulihan tata-hubungan manusia dan lingkungan hidup. Sebagaimana

\footnotetext{
${ }^{4}$ Koesnadi Hardjasoemantri, Hukum Tata Lingkungan, edisi keenam, cetakan kesebelas, Yogyakarta: Gadjah Mada University Press, 1994, h. 22.

${ }^{5}$ Sierra Club v. Morton 405 U.S. 727 (1972).

${ }^{6}$ Mas Achmad Santosa dan Margareta Quina, Gerakan Pembaruan Hukum Lingkungan Indonesia dan Perwujudan Tata Kelola Lingkungan yang Baik dalam Negara Demokrasi, Jurnal Hukum Lingkungan, Vol. 1, Issue 1, Januari 2014, dikutip dari Susan R. Schrepfer, Establishing Administrative Standing: The Sierra Club and the Forest Service 1897-1956, The Pacific Historical Review, Vol. 58, No. 1, 1989, h. 55-81.
} 
menurut Munadjat Danusaputro bahwa salah satu sarana ampuh dalam rangka melindungi lingkungan hidup adalah hukum, hukum yang mengatur perlindungan lingkungan hidup (Environmental Protection Law). ${ }^{7}$ Sehubungan dengan itu, idealnya instrumen-instrumen hukum tersebut haruslah mampu merombak paradigma hukum lingkungan klasik yang lebih berorientasi kepada penggunaan lingkungan (use-oriented law) menjadi hukum lingkungan modern yang berorientasi kepada lingkungan (hidup) itu sendiri (environmental oriented law). Sehingga dapat disadari bahwa lingkungan hidup menyandang haknya sendiri dan bukan bagian instrumental dari hak asasi manusia semata.

Tawaran konsep tersebut diharapkan dapat bermuara pada diakuinya eksistensi Lingkungan Hidup sebagai Subjek Hukum yang akan berdampak pada pembaharuan legal standing dalam sengketa lingkungan hidup. Elaborasi tentang 'apa, mengapa dan bagaimana' tawaran konsep Lingkungan Hidup sebagai Subjek Hukum ini, direpresentasikan dalam rumusan masalah sebagai berikut:

1. Redefinisi Relasi Hak Asasi Manusia dan Hak Asasi Lingkungan Hidup dalam Dimensi Etika

2. Redefinisi Relasi Hak Asasi Manusia dan Hak Asasi Lingkungan Hidup dalam Dimensi Konstitusi

Selanjutnya sebelum mengelaborasi lebih lanjut, perlu disampaikn limitasi perspektif atas konsep subjek hukum terlebih dahulu. Kemustahilan membebankan kewajiban kewajiban kepada lingkungan hidup, membuat J.G. Merrills berpendapat bahwa lingkungan hidup tidak dapat dikatakan sebagai subjek hukum oleh karena subjek hukum mempunyai hak dan kewajiban. ${ }^{8}$ Terkait dengan pendapat tersebut, menarik untuk direnungkan terkait hakikat dari subjek hukum dalam konteks dewasa ini. Bahwa orientasi dari entitas subjek hukum adalah menyandang hak dan tidak mesti menanggung kewajiban. Dapat dilihat bagaimana sejatinya anak yang baru lahir pun merupakan subjek hukum, bahkan dalam civil law dikenal ungkapan (maxim) nasciturus pro iam nato hebetur, yang dapat diartikan bahwa anak yang belum lahirpun, yang masih dalam kandungan, dianggap telah dilahirkan apabila kepentingan memerlukan. ${ }^{9}$ Jika dikaitkan dengan eksistensi kewajiban, maka mustahil pula membebankan kewajiban bagi seorang bayi, terlebih pada 'calon' bayi yang masih dalam kandungan. Meskipun demikian, tidak berarti bayi tersebut bukan subjek hukum.

Dengan reinterpretasi terhadap kewajiban, kiranya keraguan atas relevansi konseptualisasi lingkungan hidup sebagai subjek hukum dengan mendalilkan bahwa lingkungan hidup tidak memiliki kewajiban hukum dapat terbantahkan. Dalam perkembangan hukum di dunia, kerap

\footnotetext{
${ }^{7}$ Munadjat Danusaputra, Op. Cit., h. 70.

${ }^{8}$ Suparto Wijoyo, Penyelesaian Sengketa Lingkungan (Environmental Disputes Resolution), Airlangga University Press, Surabaya, 2003, h, 50, dikutip dari J.G. Merrills, Penyelesaian Sengketa Internasional, Tarsito, Bandung, 1986, h. 69.

${ }^{9}$ Peter Mahmud Marzuki, Pengantar Ilmu Hukum, edisi revisi, cetakan ketujuh, Prenada Media Group, Jakarta, 2008, h. 206
} 
kali sesuatu yang sebelumnya dianggap mustahil atau tidak terfikirkan (unthinkable) kemudian benar-benar menjadi kenyataan. Sebagaimana pada mulanya hanya sebagaian manusia saja yang dianggap memiliki hak, hingga semua manusia dianggap setara dan memiliki hak asasi yang setara. Bahkan saat ini kita telah terbiasa dengan konsep corporation having its own rights dan being a person serta citizen, dimana konsep tersebut tidak dikenal sebelumnya dalam hukum. ${ }^{10}$ Demikian pula kiranya posisi konsep lingkungan hidup sebagai subjek hukum yang 'terkesan' asing dan unthinkable namun tidak menutup kemungkinan akan menjadi familiar dan akrab dalam hukum secara universal.

\section{B. Pembahasan}

\section{Redefinisi Etis}

Terdapat sebuah diskursus dalam relasi antara hak asasi manusia dan hak asasi alam. Terkadang dalam tataran praktis, negara maupun aktivis pejuang lingkungan dihadapkan pada pilihan: manusia (dalam aspek pembangunan) atau lingkungan hidup? Hal tersebut nampaknya disebabkan oleh pendikotomian antara hak asasi manusia dan hak asasi lingkungan hidup. Padahal keduanya merupakan satu kesatuan yang tidaklah bijak untuk memilih salah satu dan mengeliminasi yang lainnya. Hak lingkungan hidup memang harus dikeluarkan dari pandangan konvensional bahwa ia hanyalah unsur intrumental dari hak asasi manusia. Namun, bukan berarti dipisahkan kemudian didikotomikan. Lebih tepatnya dibutuhkan redefinisi. Jika diibaratkan dengan sebuah bangunan maka hak asasi lingkungan hidup adalah sebuah rumah dan hak asasi manusia adalah salah satu kamar di dalamnya. Sehingga konstruksi dan penegakan hukum yang berbasis ekologis tidak semestinya mendegradasikan nilai-nilai hak asasi manusia.

Ton Dietz membagi secara sederhana gerakan lingkungan menjadi eco-fascism, ecodevelopmentalism dan eco-populism. ${ }^{11}$ Eco-fascism atau faham fasis konservasi lingkungan dimana gerakan ini berorientasi total pada kelestarian lingkungan adalah untuk lingkungannya itu sendiri. Sayangnya frasa lingkungan hidup di sini tidak dipahami secara holistis dan menganggap manusia (misalnya) berada diluar cakupan lingkungan. Sterilisasi atau 'dimurnikannya' lingkungan (misalnya hutan) dari masyarakat yang telah turun temurun mendiami kawasan tersebut demi menjaga kelestarian lingkungan/sumberdaya alam di hutan tersebut, dapat dibenarkan dalam perspektif Eco-fascism.

Eco-developmentalism atau pembangunan lingkungan dengan semboyannya yang sangat dikenal yaitu pembangunan berkelanjutan/sustainable development. Gerakan konservasi lingkungan ini berorientasi pada fungsi lingkungan dalam pembangunan. Lingkungan perlu dilestarikan, karena hanya melalui konservasi/pelestarian lingkungan tersebut yang akan dapat

\footnotetext{
${ }^{10}$ Koesnadi Hardjasoemantri, Hukum Tata Lingkungan, edisi kedelapan, cetakan kedelapan belas, Gadjah Mada University Press, Yogyakarta, 2005, h. 431.

${ }^{11}$ Mansour Fakih, "kata pengantar" dalam Ton Dietz, Pengakuan Hak Atas Sumber Daya Alam: Kontur Geografi Lingkungan Politik, (terjemahan Roem Topatimasang), Yogyakarta: Pustaka Pelajar, INSIST Press dan REMDEC, 1998, h. ix.
} 
menjamin pasokan bahan baku industrinya. Alasan lingkungan hanyalah salah satu piranti dan bersifat intrumental terhadap pertumbuhan dan pembangunan ekonomi kapitalis. Gagasan Eco-developmentalism ini pun dianggap sebagai suatu bentuk kegagalan pejuang lingkungan yang berkompromi dengan industri. ${ }^{12}$ Padahal semboyan sustainable development sudah menjadi standar mainstream pada regulatory-chain negara-negara yang dianggap memiliki kesadaran lingkungan tinggi. Termasuk di Indonesia.

Ada pula eco-populism atau lingkungan kerakyatan yaitu gerakan konservasi lingkungan yang sangat berpihak kepada kepentingan rakyat banyak: konservasi lingkungan untuk kesejahteraan masyarakat. Semboyan mereka yang paling terkenal misalnya "Forest For People!" atau 'hutan untuk rakyat'. ${ }^{13}$ Gerakan ini berorientasi pada pemanfaatan lingkungan yang bukan menitikberatkan pada kepentingan pemodal dan industri, bukan pula untuk kepentingan alam secara fasis. Kepentingan yang diperjuangkan adalah kepentingan rakyat pada umumnya. Khusus pada eco-populism, Ton Dietz membaginya menjadi dua, yaitu: strong eco-populism dan weak eco-populism. Strong eco-populism mengandalkan secara total kearifan lokal dari lingkungan tertentu dan mengevaluasi secara serius pengaruh inovasiinovasi modern yang dianggap keliru. ${ }^{14}$ Agak berbeda dengan weak eco-populism yang memadu-padankan kearifan lokal dengan inovasi-inovasi ilmiah modern dalam upaya konservasinya. $^{15}$

Apa yang diklasifikasikan oleh Ton Dietz nampaknya memang masih mendikotomikan secara jelas antara hak lingkungan hidup dan hak asasi manusia. Ketika dikotomi masih terjadi maka tentunya akan turut hadir pula pilihan sulit: manusia atau alam? Untuk itu apa yang ditawarkan dalam tulisan ini (yang diistilahkan dengan ekokrasi) memandang permasalahan kompleks ini secara holistis. Bahwa berbicara mengenai kepentingan lingkungan hidup berarti termasuk berbicara tentang manusia, sebab manusia adalah subsistem dari lingkungan hidup itu sendiri. Selanjutnya tinggal bagaimana kedaulatan lingkungan yang ditawarkan tersebut dapat ditransformasikan dalam konteks bernegara. Lebih lengkapnya dalam konteks negara hukum.

Konsep negara hukum, baik konsep rule of law maupun konsep rechtsstaat menempatkan pengakuan dan perlindungan terhadap hak-hak asasi manusia sebagai titik sentral. Untuk melindungi hak-hak asasi manusia, konsep the rule of law mengedepankan prinsip equality before the law dan konsep rechsstaat mengedepankan prinsip wetmatigheid kemudian menjadi rechtmatigheid. ${ }^{16}$ Hal ini tentunya membuat setiap 'bangunan' Negara Hukum akan secara lazim berorientasi antroposentris. Dalam kaitannya dengan etika lingkungan, antroposentrisme adalah teori etika lingkungan hidup yang memandang manusia sebagai

\footnotetext{
${ }^{12}$ A. Sonny Keraf, Etika Lingkungan, Jakarta: Penerbit Buku Kompas, 2002. h. 183.

${ }^{13}$ Mansour Fakih, "kata pengantar" dalam Ton Dietz, Op. Cit. h. xi.

${ }^{14}$ Ton Dietz, Op. Cit. h. 40.

${ }^{15}$ Op. Cit. h. 41

${ }^{16}$ Philipus M. Hadjon, Perlindungan Hukum bagi Rakyat di Indonesia, Surabaya: Peradaban, 2007, h.79-80.
} 
pusat dari sistem alam semesta. Antroposentrisme juga merupakan teori filsafat yang mengatakan bahwa nilai dan prinsip moral hanya berlaku bagi manusia dan bahwa kebutuhan dan kepentingan manusia mempunyai nilai paling tinggi dan paling penting. Dalam perspektif teori ini, etika hanya berlaku pada manusia. Hal tersebut bermuara pada pemikiran bahwa segala tuntutan mengenai perlunya kewajiban dan tanggung jawab moral manusia terhadap lingkungan hidup dianggap sebagi tuntutan yang berlebihan, tidak relevan, dan tidak pada tempatnya. $^{17}$

Kewajiban dan tanggung jawab moral manusia terhadap lingkungan hidup tidak dianggap sebagai perwujudan kewajiban dan tanggung jawab moral manusia terhadap alam. Kewajiban dan tanggung jawab moral manusia terhadap lingkungan hidup dipandang sebatas intrumen dalam upaya pemenuhan kepentingan sesama manusia. Kewajiban dan tanggung jawab terhadap alam hanya merupakan perwujudan (cerminan) kewajiban dan tanggung jawab moral terhadap sesama manusia itu sendiri. ${ }^{18}$

Tentu akan sangat tidak bijaksana jika gagasan 'egoisme' antroposentris tersebut tetap dipertahankan dengan kondisi lingkungan hidup yang mengancam kelangsungan kehidupan seluruh organisme. Berkaca pada sejarah perkembangan ilmu pengetahuan, manusia pernah terperangkap pada kesalahan asumsi tentang alam raya. Dimana sebelum 'dicerahkan' oleh Nicolas Copernicus (1473-1543) mayoritas umat manusia berasumsi bahwa bumi adalah pusat tata surya (bahkan alam semesta). ${ }^{19}$ Tanpa bermaksud untuk mengurangi esensi keistimewaan manusia, dibutuhkan kesadaaran bahwa manusia adalah bagian dari lingkungan hidup itu sendiri. Oleh karena itu kejemawaan antroposentris tidak lagi relevan untuk dipertahankan dalam peradaban manusia modern.

Dunia (alam semesta) merupakan suatu 'sistem ekologi' yang utuh dan menyeluruh sedangkan pada hakikatnya Bumi hanya merupakan 'sub-sistem ekologi'. Namun secara lazim dan populer, penggunaan istilah ekologi merujuk kepada sistem ekologi yang berada di Bumi. Adapun umat manusia hanya merupakan sub-sistem dalam realita ekosistem dalam sistem ekologi di Bumi. ${ }^{20}$ Kenyataan tersebut seharusnya menjadi acuan dalam upaya menggeser paradigma antroposentris.

Atas usangnya relevansi antroposentis dalam memahami relasi manusia dan lingkungan hidup maka hadirlah ekosentrisme sebagai alternatif perspektif. Teori ekosentrisme berorientasi pada pemahaman/pendekatan komprehensif atas moral tentang lingkungan.

\footnotetext{
${ }^{17}$ A. Sonny Keraf, Etika Lingkungan Hidup, PT Kompas Media Nusantara, Jakarta, 2010, h. 47-48.

${ }^{18}$ Ibid, h. 48.

${ }^{19}$ J. Donald Walters, Hope for A Better World: Menuju Komunitas Kooperatif, Yogyakarta: Penerbit Kanisius, 2005, h.32-35

${ }^{20}$ Munadjat Danusaputra, Op. Cit, h. 66-67.
} 
Kepedulian moral diperluas sehingga mencakup komunitas ekologis seluruhnya, baik yang hidup maupun tidak. ${ }^{21}$

Membicarakan dan mengupayakan eksistensi hak lingkungan hidup tidak terlepas dari pembicaraan tentang teori-teori etika lingkungan. Perkembangan hukum lingkungan hidup mengemukakan pula wacana-wacana seperti animal rights (hak hewan) ${ }^{22}$ dan plants rights (hak tumbuhan $)^{23}$. Kedua hak tersebut selanjutnya diupayakan untuk disandingkan dengan hak asasi manusia. Pandangan Tom Regan berorientasi pada pemikiran bahwa hewan memiliki hak karena mereka memiliki apa yang disebut inherent value ${ }^{24}$ dimana secara moral manusia berkewajiban untuk berinteraksi atas hewan dengan menghormati inherent value tersebut. Penghormatan tersebut diwujudkan dalam bentuk pernyataan sikap bahwa hewan tidak boleh dijadikan bahan percobaan untuk kegiatan ilmiah dan sebagainya. ${ }^{25}$

Disandingkannya human rights, animal rights dan plants rights merupakan pembicaraan utama dalam etika lingkungan model biosentrisme. Biosentrisme terkadang disamakan begitu saja dengan ekosentrisme. Keduanya memang memiliki banyak kesamaan akan tetapi tetap sebuah konsep yang berbeda. Perbedaan paling mendasar dari keduanya adalah bahwa cakupan dalam biosentrisme meliputi seluruh entitas yang 'hidup'. Adapaun ekosentrisme cakupannya lebih holistis karena mencakup seluruh anggota ekologis, baik yang hidup maupun yang tidak hidup. ${ }^{26}$ Pembicaraan ekosentrisme tidak memandang kepentingan hak antar spesies secara terpisah. Lebih jauh, yang dibicarakan adalah keharmonisan antar entitas dalam suatu sistem ekologi yang holistis.

Pandangan biosentrisme klasik kiranya tidak relevan diterapkan dalam rangka keberlangsungan keselarasan hidup antar komunitas biotis itu sendiri. Dapat dibayangkan bagaimana atas nama animal rights dan plants rights yang disejajarkan dengan human rights sehingga rantai makanan yang selama ini ada sebagai realitas alami kehidupan akan dibatasi oleh hak-hak yang dilindungi secara imajinatif dan berlebihan. Bukan tidak mungkin hal tersebut malah akan mengakibatkan kepunahan bagi setiap entitas.

Leopold menggambarkan hubungan antar komunitas biotis tersebut dalam bentuk 'piramida bumi'. Digambarkan dalam piramida tersebut rantai makanan yang kompleks dan seolah-olah tersusun acak, akan tetapi stabilitasnya membuktikan bahwa struktur tersebut

${ }^{21}$ Antonius Atosokhi Gea \& Antonina Panca Yuni Wulandari, Relasi dengan Dunia, Jakarta: PT Elex Media Komputindo, 2005, h. 58-59.

${ }^{22}$ Lihat Tom Regan, The Case for Animal Rights, Barkeley: Univ. of California Press, 1983.

${ }^{23}$ Lihat Michael Marder, "Should Plants Have Rights?", <http://www.michaelmarder.org/articles-etc/textsin-pdf/> , diunduh 12 Oktober 2016.

${ }^{24}$ A. Sony Keraf mengistilahkan inherent value sebagai nilai yang berharga yang melekat pada diri setiap mahluk hidup. Lihat A. Sony Keraf, Etika Lingkungan, Jakarta: Penerbit Buku Kompas, 2002, h. 49.

${ }^{25}$ A'an Efendi, "Hak Hewan: Pemikiran, Perbedaan dan Praktik di Pengadilan”, Rechtldee, Jurnal Hukum, Vol. 10, No. 2, Desember 2015, h. 248-249.

${ }^{26}$ A. Sony Keraf, Etika Lingkungan, Jakarta: Penerbit Buku Kompas, 2002, h. 75. 
sangat rapi dan terencana. ${ }^{27}$ Pemikiran Leopold yang selanjutnya dikenal dengan 'etika Bumi' menjawab dengan bijaksana pewacanaan kesetaraan hak antar komunitas biotis, bahwa: di satu pihak bumi dan segala isinya perlu dilestarikan. Akan tetapi, karena ada satu kesatuan yang saling tergantung dan saling terkait di antara semua anggota bumi sebagai komunitas biotis, eksistensi yang satu mendukung eksistensi yang lain dalam sebuah rantai makanan yang kompleks. Di pihak lain, kita membutuhkan makhluk lain untuk mempertahankan hidup. Hanya saja, ini tidak berarti eksistensi mereka hanya bernilai sekadar bagi kehidupan kita. Itu sebabnya, bagi Leopold, manusia boleh saja membunuh binatang tertentu atau menebang pohon tertentu untuk memenuhi kebutuhannya asalkan tindakan itu tidak mengganggu dan merusak "integritas, stabilitas, dan keindahan komunitas biotis." Bahkan ketika ada makhluk hidup yang mengganggu komunitas biotis, kita berkewajiban untuk membasminya. Eksistensi mereka, demikian pula eksistensi manusia, bernilai justru karena menunjang "integritas, stabilitas dan keindahan komunitas biotis." Dan akan, tidak bernilai kalau cenderung sebaliknya. $^{28}$

Ekosentrisme semakin dipertajam dan diperdalam melalui deep ecology dan ecosophy yang memberikan reinterpretasi terhadap relasi antar komunitas ekologis dalam upaya mengakomodir kepentingan seluruh komunitas ekologis. Deep ecology menuntut suatu etika baru yang tidak berpusat pada manusia, melainkan berpusat pada keseluruhan kehidupan dengan upaya mengatasi persoalan lingkungan hidup. ${ }^{29}$

Deep ecology adalah salah satu varian pengembangan teori ekosentrisme dalam ragam teori etika lingkungan hidup yang sekarang ini populer. Sebagai sebuah istilah, Deep Ecology pertama kali diperkenalkan oleh Arne Naess, seorang filsuf Norwegia, pada 1973. Dalam artikelnya yang berjudul "The Shallow and the Deep, Long-range Ecological Movement: A Summary", Naess membedakan antara shallow ecological movement dan deep ecological movement. ${ }^{30}$

Deep Ecology menawarkan perspektif etika yang tidak berpusat hanya pada manusia, tetapi berorientasi pada makhluk hidup secara keseluruhan dalam rangka upaya mengatasi persoalan lingkungan hidup. Dalam Deep Ecology, manusia dan kepentingannya tidak lagi dipandang sebagai pusat dari dimensi moral. Deep Ecology tidak hanya memusatkan perhatian pada kepentingan jangka pendek, tetapi jangka panjang. Prinsip moral yang dikembangkan Deep Ecology menyangkut kepentingan seluruh komunitas ekologis. ${ }^{31}$ Dengan demikian, manusia dengan kesadaran penuh diminta untuk membangun suatu kearifan budi

\footnotetext{
${ }^{27}$ Op. Cit., h. 62, dikutip dari Aldo Leopold, "The Land Ethics", dalam A Sand Country Almanac: And Sketches Here and There, 1949.

${ }^{28}$ Op. Cit., h. 63.

${ }^{29}$ Loc. Cit..

${ }^{30}$ A. Sonny Keraf, Etika Lingkungan Hidup, Jakarta: Penerbit Buku Kompas, 2010, h. 2, dikutip dari Op. Cit. h. 89.

${ }^{31}$ Ibid.
} 
dan kehendak untuk hidup dalam keharmonisan dengan seluruh isi alam semesta sebagai suatu gaya hidup yang berusaha semakin menyelaraskan diri dengan alam.

Fase selanjutnya dari ekosentrisme adalah transformasinya menjadi ekokrasi. Telah dikenal beberapa teori kedaulatan, yaitu Kedaulatan Tuhan yang kenal dengan Teokrasi, gagasan Kedaulatan Rakyat yang dikenal dengan demokrasi dan Kedaulatan Hukum yang terkait dengan Nomokrasi. Maka Jimly Assiddiqie dalam Green Constitution-nya merasa perlu memperkenalkan konsep Ekokrasi yang dikaitkan dengan Kedaulatan Lingkungan. ${ }^{32}$

Dalam konteks bernegara, kesadaran ekokrasi yang diharapkan tentunya bukanlah kesadaran sporadis antar individu-individu yang berupa riak-riak belaka. Dibutuhkan kesadaran ekokrasi yang bersifat komprehensif. Kesadaran yang ditandai dengan lahirnya jaminan dalam dimensi hukum. Apabila kedaulatan hak lingkungan hidup diakomodir dalam tingkat konstitusi, maka seluruh aturan perundang-undangan, kebijakan-kebijakan dan seluruh interaksi pemerintahan akan bersinergi dengan orientasi pengakuan dan perlindungan hak lingkungan hidup.

\section{Redefinisi Konstitusional}

Relasi antara hak asasi manusia dan lingkungan hidup dapat dilihat dari hak atas lingkungan hidup hidup menjadi instrumen dalam HAM. Bahwa salah satu hak yang asasi bagi manusia adalah hak atas lingkungan hidup yang baik dan sehat. ${ }^{33}$ Adapun hak atas lingkungan hidup tersebut bukanlah hak yang berdiri sendiri. Terdapat hak-hak turunan (derivatif) yang akan menentukan sejauh mana kualitas hak atas lingkungan dapat terpenuhi. Terdapat dua aspek yang membentuk hak atas lingkungan, yakni aspek prosedural dan aspek substantif. ${ }^{34}$ Hak substantif adalah aspek substansial dari hak atas lingkungan hidup. Dimana setiap orang berhak atas lingkungan hidup yang baik dan sehat. ${ }^{35}$ Adapun aspek prosedural merupakan hak-hak derivatif dari hak atas lingkungan yang bersifat prosedural atau menjadi pilar dalam mewujudkan pemenuhan hak atas lingkungan secara substansial. Hak-hak prosedural dari hak atas lingkungan ini disepakati di Aarhus, Denmark dalam tajuk 'Aarhus Convention 1998'. Pilar-pilar yang tergolong hak prosedural tersebut terdiri atas: access to information, public participation in decision-making dan access to justice. ${ }^{36}$ Hak-hak prosedural tersebut dalam konteks Indonesia selanjutnya diadopsi dalam peraturan perundang-

${ }^{32}$ Jimly Asshiddiqie, Green Constitution: Nuansa Hijau Undang-Undang Dasar Negara Republik Indonesia Tahun 1945, Jakarta: PT. Rajagrafindo Persada, h. 117.

${ }^{33}$ Lihat Pasal 28H ayat (1) Undang-Undang Dasar Negara Republik Indonesia Tahun 1945.

${ }^{34}$ Agung Wardana, "Hak Atas Lingkungan: Sebuah Pengantar Diskusi”, dalam Jurnal Advokasi, Volume 3 , h. 123.

${ }^{35}$ Lihat Pasal 28H ayat (1) Undang-Undang Dasar Negara Republik Indonesia Tahun 1945 dan Pasal 65 ayat (1) Undang-Undang Nomor 32 Tahun 2009 tentang Perlindungan dan Pengelolaan Lingkungan Hidup

${ }^{36}$ Jonas Ebbesson et al., The Aarhus Convention: an Implementation Guide, Geneva: United Nation, 2014, h.19. 
undangan $^{37}$ yang dikenal sebagai hak atas akses informasi, akses partisipasi, dan akses keadilan dalam memenuhi hak atas lingkungan hidup yang baik dan sehat.

Dalam konteks Indonesia, pasca amandemen ke-dua Undang-Undang Dasar Negara Republik Indonesia Tahun 1945, dapat dilihat bagaimana lebih banyak dan lebih lengkap dimasukkan pasal-pasal tentang HAM. Sebagaimana pada (khususnya namun tidak terbatas pada) Bab XA Undang-Undang Dasar Negara Republik Indonesia Tahun 1945 dimana dapat dikelompokkan pasal-pasal terkait HAM tersebut kedalam kelompok 'hak sipil dan hak politik' serta 'hak ekonomi, sosial dan budaya'.

Pasal 28A, 28I ayat (1), 28D ayat (1), ayat (3), ayat (4), 28E ayat (1), ayat (2), ayat (3), 28F, 28G ayat (1), ayat (2), dan Pasal 28I ayat (1) dan (2) dapat digolongkan dalam pasalpasal yang mengatur hak sipil dan hak politik. Adapun Pasal 28B ayat (1), ayat (2), 28C ayat (1), ayat (2), 28D ayat (2), 28E ayat (1), 28H ayat (1), ayat (2), ayat (3), ayat (4) dan pasal 28I ayat (3) mengtur hak ekonomi, sosial dan budaya. ${ }^{38}$ Dalam kaitannya dengan lingkungan hidup, menarik untuk diamati bagaimana hak atas lingkungan hidup diletakkan secara tidak terpisah dengan hak-hak lain dalam pasal $28 \mathrm{H}$ ayat (1). Dimana hak atas lingkungan hidup, diletakkan bersamaan dengan hak kesejahteraan, hak atas tempat tinggal dan hak pelayanan kesehatan. Terlepas dari aspek lingkungan hidup, menurut Herlambang P. Wiratraman banyak sekali ditemukan kesamaan substantif sejumlah pasal-pasal hak asasi manusia, baik di dalam maupun di luar Bab XA, sehingga secara konseptual tumpang tindih, repetitif dan tidak ramping pengaturannya. ${ }^{39}$ Keterkaitan antara lingkungan hidup dan hak asasi manusia sebagaimana dapat diamati pada pasal $28 \mathrm{H}$ ayat (1) memberikan gambaran relasi antara lingkungan hidup dan hak asasi manusia tersebut. Dimana lingkungan hidup hanya merupakan instrumen pemenuhan HAM.

Bukan hal aneh jika dalam pasal $28 \mathrm{H}$ ayat (1) tersebut hak atas lingkungan hidup 'ditumpuk' dengan hak lain semisal kesehatan dan tempat tinggal. Hal tersebut karena bab XA memang dirancang kusus sebagai bab tentang HAM. Jika memperhatikan dan mencermati sejarah lahirnya pasal $28 \mathrm{H}$ ayat (1) ini pun, tidak didapati adanya pendekatan lingkungan. Perdebatan dan pertimbangan terkait lahirnya pasal ini berputar pada pendekatan tata negara, penyelesaian kasus pelanggaran HAM, pendekatan ekonomi, kebebasan pers dan sebagainya. ${ }^{40}$ Bahwa dimasukkannya frasa lingkungan hidup dalam pasal tersebut memang

\footnotetext{
${ }^{37}$ Lihat Pasal 65 ayat (2) Undang-Undang Nomor 32 Tahun 2009 tentang Perlindungan dan Pengelolaan Lingkungan Hidup.

${ }^{38}$ R. Herlambang Perdana Wiratraman, "Hak-Hak Konstitusional Warga Negara Setelah Amandemen UUD 1945: Konsep, Pengaturan dan Dinamika Implementasi" dalam Jurnal Hukum Panta Rei, Volume 1, No. 1 Desember 2007, h. 5,6,7.

${ }^{39}$ Ibid., h. 7.

${ }^{40}$ Mahkamah Konstitusi Republik Indonesia, Naskah Komprehensif Perubahan Undang-Undang Dasar Negara Republik Indonesia Tahun1945: Latar Belakang, Proses dan Hasil Pembahasan 1999-2002, Buku VIII Warga Negara dan Penduduk, Hak Asasi Manusia dan Agama, edisi revisi, Sekretarian Jenderal dan Kepaniteraan MK, Jakarta, 2010, h. 213-362.
} 
diperuntukkan bagi kesejahteraan manusia semata. Pendekatan yang digunakan dalam memandang lingkungan sangat berorientasi ekonomis. Sebagaimana disampaikan Ichsan Tanjung sebagai perwakilan Ikatan Sarjana Ekonomi Indonesia (ISEI) dalam rapat dengar pendapat umum (RPDU): ${ }^{41}$

Kita mendengar bagaimana hasil-hasil hutan kita juga akan terkena hal semacam itu ${ }^{42}$. Jadi, akan ada ecolabelling di negara-negara Eropa semacam itu. Dan jangan kaget kalau produksi kita akan dipertanyakan berdasarkan input-input yang disampaikan oleh LSM di sini ke luar negeri bahwa itu diproduksi secara melanggar HAM entah upahnya, entah fasilitas ini itu, kesehatan, wanita hamil masih dipekerjakan. Saya kira contoh-contohnya akan semakin banyak. Jadi, yang kami mau garis bawahi di sini bahwa Bapak Ibu sekalian ekonomi pun tidak bisa lepas dari HAM dan demokrasi. Itu juga satu alasan mengapa kita memandang ada hal yang tidak benar, kalau itu dipercayakan pada penyelenggara yang sangat berkuasa dan bisa memainkan banyak hal. Jadi, serahkan kepada swasta tetapi dengan asumsi dasar hukum harus berlaku, dan dalam rangka memberlakukan hukum ini kita jangan keder dengan LSM, banyak fungsinya mereka itu.

Demikian bagaimana gambaran relasi antara lingkungan hidup dan hak asasi manusia dalam pasal $28 \mathrm{H}$ ayat (1). Bahwa dari segi original intent, pasal ini memang tidak diperuntukkan sebagai perlindungan hukum bagi lingkungan hidup. Lingkungan hidup hanya dijamin sejauh relasinya sebagai intrumen kesejahteraan dalam dimensi hak asasi manusia. Permasalahan lingkungan hidup bukan lagi sekedar sub-isu dari isu hak asasi manusia. Dalam tingkat konstitusi, seharusnya sebuah negara hukum yang paripurna mengakomodasi kepentingan jangka panjang yang bersifat holistis. Hingga isu lingkungan hidup kemudian ditempatkan sebagai isu urgen yang dibahas khusus dan tersendiri diluar dari isu hak asasi manusia.

Hal tersebut tentunya kontras jika dibandingkan dengan apa yang terjadi di Ekuador. Pergeseran atau pembaharauan paradigma terhadap hak atas lingkungan hidup menjadi hak lingkungan hidup nampak dalam Konstitusi Ekuador 2008. Dimana lingkungan hidup mendapatkan hak konstitusional sebagai subjek hukum (penyandang hak) dalam konteks pergaulan hukum di Ekuador. Bahwa selain berorientasi pada konsepsi umum tentang hak asasi manusia, Konstitusi Ekuador 2008 juga mengakui adanya hak asasi yang disandang oleh lingkungan hidup sebagai sebuah eksistensi.

\footnotetext{
${ }^{41}$ Ibid., h. 244-245, dikutip dari Sekretariat Jenderal MPR-RI, Risalah Perubahan Undang-Undang Dasar Negara Republik Indonesia Tahun 1945 (1999-2002) Tahun Sidang 2000 Buku Dua, Sekretariat Jenderal MPRRI, Jakarta, 2008), h. 205.

${ }^{42}$ Sebelumnya Ichsan Tandjung memberikan contoh hubungan antara demokrasi (dalam kaitannya dengan HAM) dengan ekonomi dengan menggambarkan bagaimana barang produksi yang selanjutnya dicekal di negaranegara Eropa karena proses produksinya yang cenderung melanggar HAM.
} 
Hal tersebut sebagaimana dalam Título II, art. 10, yang menyatakan bahwa: "Las personas, comunidades, pueblos, nacionalidades y colectivos son titulares y gozarán de los derechos garantizados en la Constitución y en los instrumentos internacionales. La naturaleza será sujeto de aquellos derechos que le reconozca la Constitución." 43 Dalam terjemahan ke dalam bahasa Inggris berarti: "Persons, communities, peoples, nations and communities are bearers of rights and shall enjoy the rights guaranteed to them in the Constitution and in international instruments. Nature shall be the subject of those rights that the Constitution recognizes for it. ",44

Sebagaimana dapat dilihat dalam level konstitusi, bagaimana Ekuador membuat 'gebrakan' dalam perspektif konstitusinya yang selanjutnya berdampak pada pembaharuan legal standing dalam sengketa lingkungan di Ekuador.

Dampak tersebut dapat dilihat pada kasus yang menjadi landmark wajah baru penegakan hukum lingkungan di Ekuador bahkan dunia internasional. Kasus Wheeler melawan Director de la Procuraduria General Del Estado de Loja ${ }^{45}$ merupakan the first successful case enforcing rights of nature di Ekuador bahkan di dunia. Richard Frederick Wheeler dan Eleanor Geer Huddle mengajukan gugatan ke pengadilan dengan mengatasnamakan (sebagai wakil dari) sungai Vilcabamba, yang terletak di Vilcabamba (Valley of Longevity), Ekuador. Sungai tersebut terkena dampak negatif atas pelebaran jalan yang dilakukan oleh pemerintah Provinsi Loja. Sejak tahun 2008 pelebaran jalan telah menyebabkan kerusakan pada Rio (sungai) Vilcabamba. ${ }^{46}$

Richard Frederick Wheeler dan Eleanor Geer Huddle memiliki sebuah pertanian di wilayah Vilcabamba. Secara nyata propeti milik mereka tidak mengalami kerusakan. ${ }^{47}$ Dengan kata lain secara nyata tindakan yang mengakibatkan kerusakan lingkungan yang dilakukan oleh pemerintah Provinsi Loja tidak menimbulkan kerugian materiil atas pihak Richard Frederick Wheeler dan Eleanor Geer Huddle. Sehingga bila direfleksikan pada hak gugat konvensional terkait kerugian, maka mereka berdua tidak memiliki legal standing. Mereka bahkan bukanlah warga Ekuador asli, sehingga standing to sue akan semakin sulit bagi mereka.

Terbukti betapa sulitnya mereka mengupayakan untuk menghentikan aktivitas yang merusak ekosistem sungai Vilcabamba. Sejak 2008 jalur non litigasi kerap mereka tempuh

\footnotetext{
${ }^{43}$ República del Ecuador, Constituciones de 2008, Título II.

${ }^{44}$ Republic of Ecuador: Constitution of 2008, English Translation, Georgetown University.

${ }^{45}$ Wheeler y Huddle en contra de Director de la Procuraduria General del Estado en Loja (30 March 2011) Juicio No. 11121-2011-10, Casillero No. 826, Corte Provincial de Justica de Lojo.

${ }^{46}$ Norie Huddle, "World's First Successful 'Rights of Nature' Lawsuit", Laman <http://www.kosmosjournal.org/article/worlds-first-successful-rights-of-nature-lawsuit-2/>, diunduh 8 Agustus 2016.

${ }^{47}$ Ibid.
} 
namun selalu gagal. Hingga pada tahun 2011, setelah mereka menyadari bahwa dalam Konstitusi Ekuador terdapat norma-norma yang menjamin hak asasi lingkungan hidup, tepatnya pada:

Título II, art. 10, yang menyatakan bahwa: "Las personas, comunidades, pueblos, nacionalidades y colectivos son titulares y gozarán de los derechos garantizados en la Constitución y en los instrumentos internacionales. La naturaleza será sujeto de aquellos derechos que le reconozca la Constitución." 48 Dalam terjemahan ke dalam bahasa Inggris berarti: "Persons, communities, peoples, nations and communities are bearers of rights and shall enjoy the rights guaranteed to them in the Constitution and in international instruments. Nature shall be the subject of those rights that the Constitution recognizes for it." 49

Dengan demikian secara konstitusional Lingkungan Hidup diakui sebagai subjek hukum yang menyandang hak dan dapat dikuasakan untuk diwakili memperjuangkan mempertahankan haknya di hadapan hukum. Lebih jauh dalam Constituciones de 2008 República del Ecuador juga pihak-pihak yang dijamin haknya untuk mewakili hak lingkungan hidup di hadapan hukum, sebagaimana pada Artikel 71 Konstitusi Ekuador $2008^{50}$ dikemukakan bahwa Every person, people, community or nationality, will be able to demand the recognitions of rights for nature. Hak yang dimaksudkan merupakan the right to exist, persist, maintain and regenerate its vital cycles, structure, functions and its processes in evolution. ${ }^{51}$ Sehingga siapapun berhak untuk maju ke 'panggung hukum' untuk membela hak lingkungan hidup.

Akhirnya pada Januari tahun 2011, Richard Frederick Wheeler dan Eleanor Geer Huddle mangajukan gugatan atas nama Rio (sungai) Vilcabamba. Meskipun mereka kalah pada peradilan tingkat pertama, namun pada akhirnya pada 30 Maret 2011 mereka memenangkan banding. ${ }^{52}$ Demikian bagaimana langkah revolusioner monumental yang diambil oleh Ekuador dalam pengakuan hak asasi lingkungan hidup dalam konstitusinya.

Dapat dibayangkan bagaimana jika hal tersebut juga dihadirkan di Indonesia, maka penyelesaian sengketa lingkungan hidup akan berfokus 'menatap' hakikat masalah tanpa membuang energi pada aspek legal standing penggugat. Siapapun dapat mewakili lingkungan hidup dalam mengajukan gugatan. Bukan lagi melihat apakah ia terkena dampak kerugian, apakah ia NGO yang telah memenuhi syarat, atau instrumen terkait legal standing-nya.

\footnotetext{
${ }^{48}$ República del Ecuador, Constituciones de 2008, Título II.

${ }^{49}$ Republic of Ecuador: Constitution of 2008, English Translation, Georgetown University.

${ }^{50}$ Lihat República del Ecuador, Constituciones de 2008, Título II.

${ }^{51}$ Lihat Republic of Ecuador: Constitution of 2008, English Translation, Georgetown University.

${ }^{52}$ Norie Huddle, Loc. Cit.
} 
Sepanjang ia dapat membuktikan bahwa telah terjadi pelanggaran hak asasi lingkungan hidup maka ia berhak mewakili lingkungan hidup di hadapan hukum.

Pada akhirnya hukum bukan lagi sekedar hukum untuk hukum, bukan pula sebatas hukum untuk manusia. Lebih jauh, hukum telah berprogres sebagaimana mestinya: hukum untuk kemaslahatan alam.

\section{Penutup}

Berdasarkan uraian diatas, dapat disimpulkan bahwa ;

1. Pergeseran Antroposentrisme menjadi ekosentrisme meredefinisikan bahwa pada hakikatnya hak yang terkait lingkungan hidup bukanlah hak atas lingkungan hidup melainkan hak (yang disandang) lingkungan hidup itu sendiri sehingga dalam menghadapi problematika kompleks lingkungan hidup global dibutuhkan perspektif ekologis-holistis. Pandangan tersebut dalam ranah hukum selanjutnya diterjemahkan sebagai konsepsi ekokrasi atau kedaulatan lingkungan dalam suatu bangunan negara hukum;

2. Doktrin ekokrasi yang menempati ranah filsafat dalam "tiga lapisan ilmu hukum" selanjutnya direpresentasikan dalam dimensi teori yang mewacanakan bahwa lingkungan hidup merupakan subjek hukum. Pengakuan konstitusional terhadap hak "asasi" lingkungan hidup tersebut selanjutnya dapat memberi ruang legal standing pada siapa saja untuk mewakili lingkungan hidup di hadapan hukum.

\section{Daftar Pustaka \\ Buku}

Asshiddiqie, Jimly, Green Constitution: Nuansa Hijau Undang-Undang Dasar Negara Republik Indonesia Tahun 1945, Jakarta: PT. Rajagrafindo Persada.

Danusaputra, Munadjat, Hukum Lingkungan, Buku I, Binacipta, 1985.

Dietz, Ton, Pengakuan Hak Atas Sumber Daya Alam: Kontur Geografi Lingkungan Politik, (terjemahan Roem Topatimasang), Yogyakarta: Pustaka Pelajar, INSIST Press dan REMDEC, 1998.

Ebbesson, Jonas et al., The Aarhus Convention: an Implementation Guide, Geneva: United Nation, 2014.

Gea, Antonius Atosokhi dan Antonina Panca Yuni Wulandari, Relasi dengan Dunia, Jakarta: PT Elex Media Komputindo, 2005.

Hadjon, Philipus M., Perlindungan Hukum bagi Rakyat di Indonesia, Surabaya: Peradaban, 2007.

Hardjasoemantri, Koesnadi, Hukum Tata Lingkungan, edisi keenam, cetakan kesebelas, Yogyakarta: Gadjah Mada University Press, 1994.

Hardjasoemantri, Koesnadi, Hukum Tata Lingkungan, edisi kedelapan, cetakan kedelapan belas, Yogyakarta: Gadjah Mada University Press, 2005.

Huddle, Norie, "World's First Successful 'Rights of Nature' Lawsuit", <http://www.kosmosjournal.org/article/worlds-first-successful-rights-of-nature-lawsuit2/>, diunduh 8 Agustus 2016. 
Keraf, A. Sonny, Etika Lingkungan Hidup, PT Kompas Media Nusantara, Jakarta, 2010.

Keraf, A. Sonny, Etika Lingkungan, Jakarta: Penerbit Buku Kompas, 2002.

Mahkamah Konstitusi Republik Indonesia, Naskah Komprehensif Perubahan UndangUndang Dasar Negara Republik Indonesia Tahun1945: Latar Belakang, Proses dan Hasil Pembahasan 1999-2002, Buku VIII Warga Negara dan Penduduk, Hak Asasi Manusia dan Agama, edisi revisi, Jakarta: Sekretarian Jenderal dan Kepaniteraan MK, 2010.

Marder,Michael, "Should Plants Have Rights?", <http://www.michaelmarder.org/articlesetc/texts-in-pdf/>, diunduh 12 Oktober 2016.

Marzuki, Peter Mahmud, Pengantar Ilmu Hukum, edisi revisi, cetakan ketujuh, Jakarta: Prenada Media Group, 2008.

Mukhlish dan Mustafa Lutfi, Hukum Administrasi Lingkungan Kontemporer, Cetakan Pertama, Malang: Setara Press, 2010.

Regan, Tom, The Case for Animal Rights, Barkeley: Univ. of California Press, 1983.

Sierra Club v. Morton 405 U.S. 727 (1972).

Walters, J. Donald, Hope for A Better World: Menuju Komunitas Kooperatif, Yogyakarta: Penerbit Kanisius, 2005.

Wijoyo, Suparto, Penyelesaian Sengketa Lingkungan (Environmental Disputes Resolution), Surabaya: Airlangga University Press, 2003.

\section{Jurnal}

Efendi, A'an, "Hak Hewan: Pemikiran, Perbedaan dan Praktik di Pengadilan", Rechtldee, Jurnal Hukum, Vol. 10, No. 2, Desember 2015.

Santosa, Mas Achmad dan Margareta Quina, Gerakan Pembaruan Hukum Lingkungan Indonesia dan Perwujudan Tata Kelola Lingkungan yang Baik dalam Negara Demokrasi, Jurnal Hukum Lingkungan, Vol. 1, Issue 1, Januari 2014.

Wardana, Agung, "Hak Atas Lingkungan: Sebuah Pengantar Diskusi", dalam Jurnal Advokasi, Volume 3.

Wiratraman, R. Herlambang Perdana, "Hak-Hak Konstitusional Warga Negara Setelah Amandemen UUD 1945: Konsep, Pengaturan dan Dinamika Implementasi” dalam Jurnal Hukum Panta Rei, Volume 1, No. 1 Desember 2007.

\section{Peraturann Perundang-undangan}

Undang-Undang Dasar Negara Republik Indonesia Tahun 1945.

Undang-Undang Nomor 32 Tahun 2009 tentang Perlindungan dan Pengelolaan Lingkungan Hidup

República del Ecuador, Constituciones de 2008, Título II.

Wheeler $y$ Huddle en contra de Director de la Procuraduria General del Estado en Loja (30 March 2011) Juicio No. 11121-2011-10, Casillero No. 826, Corte Provincial de Justica de Lojo. 